\title{
TRADITIONAL CRAFT IN CLUJ-NAPOCA: BETWEEN ART, TRADITION, AND SALE
}

\author{
Cristina BOLOG \\ Babeş-Bolyai University, Cluj-Napoca, Faculty of Geography, ROMANIA \\ cpatrascu@geografie.ubbcluj.ro

\section{Raluca Georgiana BRIE} \\ Babeş-Bolyai University, Cluj-Napoca, Faculty of Geography, ROMANIA \\ raluca.brie@ymail.com
}

DOI: http://dx.medra.org/10.23740/TID120162

\section{ABSTRACT}

Knowledge of a traditional craft means living an experience and enriching the cultural activity, with a personal and community meaning, while purchasing the final products means a simple trade exchange. But currently, it is valued more the final product and not the craft itself. Being a craftsman, through knowledge and specific techniques, it is actually living the feeling, the mystery and the spirit of the craft, learned during centuries, through a long qualification as a craftsman. Traditional crafts represent a gateway to memories and to reviving the tradition, the authentic or the human skills to create unique and original products. Traditional crafts perpetuate traditions, but today we are witnessing the disappearance of true craftsmen and a focus on the commercial aspect of crafts. The paper analyses the activities of artisans' and craftsmen's continuity over centuries in Cluj-Napoca, reaching the present situation, when the focus is not on the producing act itself, but on the final product, representing an adaptation to modernity and demand, including on tourism. Our analysis explores the art as experience, aiming to differentiate its results in terms of authenticity and assessing its evolution as a result of current representations.

Keywords: tradition, creativity, uniqueness, continuity, authenticity, kitsch, traditional craft

\section{INTRODUCTION: THE CRAFT - ART AND PROFESSION}

Geographical identity refers to an "identity relationship that links a given community to its lived space" (Caldo, 1996, p. 285). The community of artisans has always been firmly rooted in its lived space, expressing it through traditional site-specific art. Crafting was adapted to different habitats, using certain resources and generating certain types of products. Moreover, the products in general, through the art of crafting, outline the "spirit of place", as defined by The Declaration of ICOMOS (2008), which perpetuates local identity, connecting, by purpose, place and person (ICOMOS, 2008, pp. 1-4).

Since ancient times, human creativity has been leading to solutions for the realisation of tasks absolutely necessary for everyday life, but also it helped to meet people's needs in a period where current technology did not exist, and the possibility of comfortable and satisfactory living standards was low. However, due to human skill and ingenuity, and despite poor conditions, people managed to create sophisticated work techniques, adapted to those times. Crafts appeared from human creativity, aiming to ensure the fulfillment of basic needs and only then, leading to the satisfaction of secondary needs and desires. 
According to the Explanatory Dictionary of the Romanian Language (DEX) (2009), the craft has the following meanings: " 1 . job; profession, occupation. 2. Branch, discipline (in science, art); science, art, considered disciplines. Style (artistic). 3. skill, dexterity, ability, talent. Art, craftsmanship; (rare) action performed skillfully, artfully. (Popular) 1. tool, instrument" (https://dexonline.ro/definitie/me\%C8\%99te\%C8\%99ug). The Law on Crafts [Legea Meșteșugurilor] shows that the craft is "an independent entrepreneurial activity caried out in order to obtain craft products and services, as small industry, based on knowledge and skills acquired through training" (http://www.senat.ro/legis/PDF\%5C2006\%5C06L904FS.pdf, pp. 12). According to the UNESCO definition adopted by the International Symposium Advisory Committee in Manila, "Crafts and the International Market: Trade and Customs Codification", in October 1997, artisanal products are "those produced by artisans, either completely by hand, or with the help of hand tools or even mechanical means, as long as the direct manual contribution of the artisan remains the most substantial component of the finished product. These are produced without restriction in terms of quantity and using raw materials from sustainable resources. The special nature of artisanal products derives from their distinctive features, which can be utilitarian, aesthetic, artistic, creative, culturally attached, decorative, functional, traditional, religiously and socially symbolic and significant" (International. Symposium on "Crafts and the International market: trade and customs codification", 1997, p. 6). Also, handicraft means "in common language [...] the goods made by using labour intensive technique" made by "skilled people who used to work with wood, clay, shells, rocks, stone, metal etc. with the help of traditional or simple tools" (Towseef et al., 2014, p. 76).

It is useful to mention that crafts are divided into two categories, the practical or utilitarian (i.e. cooperage workers, carpenters, wheelwrights, blacksmiths, etc.), so especially those who meet basic needs in the household, and arts and crafts with an aesthetic role (i.e. ceramics, textiles, and traditional costume). According to DEX (2009), artisanal products are "art produced handicrafts" and "artistic products made by craftsmen" (https://dexonline.ro/definitie/artizanat).

Therefore, the craft means alike job, profession, entrepreneurial activity, skill, dexterity, ability, talent, all these being materialised as genuine products, unique, or at least produced on a small scale; and the maker of the craft is the craftsman, the person practicing this profession.

\section{METHODOLOGY}

The paper presents the evolution of the crafts in the "treasure city" of Transylvania, Cluj-Napoca, having as main purpose underlining the current features in order to continuously shape the directions of development towards sustainability. Therefore, it was considered necessary to assess both quantitatively and qualitatively the craft products, as well as the current situation of the craftsmen in Cluj-Napoca, regarding, on one hand, the craft as a creative act, and, on the other, as an object that generates income, respectively commercial aspects.

The bibliographical study, completed with the legislation, allowed us to track in time the development of crafts in Transylvania and in Cluj-Napoca and to shape the nowadays framework. The fieldwork consisted of our participation in a series of craft fairs, with commercial and tourist aspect. It included direct observation and photography that made possible the collection and the interpretation of the statistical data on the structure craft fairs (number of existing booths, the types of sold products, authentic or inauthentic characteristics). The obtained information allowed the quantification of booths selling food and non-food products, 
but also a qualitative assessment, aiming to differentiate those offering authentic products from the inauthentic ones (characterised by poor quality, bad taste, called kitsch products).

Our analysis started from a study on What Makes a Craft Souvenir Authentic? (Littrell et al., 1993), which refers to the consumption of authentic artefacts, based on 385 descriptions tourists made of them (Littrell et al., 1993, p. 197). Adding attributes of authentic and not authentic, criteria of analysis were outlined. The criteria used by tourists to define crafts' authenticity are "uniqueness, workmanship, aesthetics and use, cultural and historical integrity, genuine appearance"; also "craftsman features and the experience in purchasing crafts products are shaping their authenticity" (Littrell et al., 1993, p. 197).

So, in order to assess the authenticity of crafts objects sold at the fairs, there were considered the following attributes of authenticity: unchanged, true, original, genuine, produced in small quantities or unique, and the following attributes of kitsch: disproportioning, the prevalence of commercial function instead of the the aesthetic one (including the sale price), the prevalence elementary or biological stimulus (erotism, vulgarity) and affective ones (sentimentalism, idealisation, dramatisation), their straight message (simple meanings, reductionist conception), transparency and directness, dilution of the symbolic function, lack of originality, and mimetic standardised expression. These attributes have been applied to the analysis of each of the present booths, for the type of exhibited products, so each one underwent an analysis according to the attributes listed above and, finally, the booth was characterised as authentic or not, according to the counted number of dominant products.

Also, thirty questionnaires were administered to craftsmen who agreed to answer. Respondents were part of "Asociația Meșterilor Populari Clujeni" [The Association of Cluj Craftsmen] that were present during the analysed fairs. After analysing their answers to the questionnaires, we carried out the quantication according to types of crafts, structure on craftsmen' age, education, experience and other useful information for identifying the craftsmen's present situation in ClujNapoca.

\section{RESULTS AND DISCUSSION}

\section{The history of the crafts in Cluj-Napoca}

The development of what we call today the craft has its roots in the Middle Ages. In the $14^{\text {th }}$ century, the town obtained privileges when "in a royal document issued on the $19^{\text {th }}$ of August 1316, the King Charles I raised Cluj as a town, called from this time forward Civitas Kulusvar" (Lukacs, 2005, p. 34). During that period, the crafts began to flourish and to spread "due to royal privileges, Cluj has grown steadily [...]" (Lukacs, 2005, p. 35). The historian Samuil Goldenberg, in his book Cluj in the $16^{\text {th }}$ Century. Production and Exchange of Goods, describes Cluj as a city with a "fast transformation from the rural organisation to the urban one and to economic prosperity"; the development of "productive forces created the necessary conditions for the development of labour division, separation of handicrafts from agriculture, the appearance of the city as a craft centre" (Goldenberg, 1958, p. 17). Also, according to Goldenberg (1958, pp. 21-23), the first customs privileges, dating from 1331, certified the protection of the craftsmen from nobles' attacks, artisans being able to sell products at fairs in the city, in the region and in the country. The craftsmen's number was growing continuously, and since the second half of the $14^{\text {th }}$ century, the largest part of the residents were dealing with crafts and trade, shaping the urban layout of the city. During the same period, arised a large number of handicraft branches, 
mentioned in the second half of the $14^{\text {th }}$ century: millers, butchers, brewers, blacksmiths, furriersand drapers, silversmiths, etc., and, during the same period, there were the first attempts to establish guilds (Pascu \& Marica, 1969, p. 20): "the first guild in Cluj was that of the skinners and furriers, founded in 1369, followed by those of the butchers, blacksmiths, carpenters, stone carvers and of the others" (Lukacs, 2005, p. 35). Although the guild of the skinners and furriers was mentioned in documents only in 1369, it is believed that it was founded earlier, at least one year before. In fact, the document from 1369 refers to the complaint of the guild against the competition with the city council and not the year when the guild established itself (Pascu, 1954, p. 84; Pascu, 1974, p. 90).

According to Pascu and Marica (1969, pp. 20-25), the importance of the craftsmen in the life of Cluj resulted from their growing number and because they considered that, together with merchants, they were entitled to obtain nobles' place. Thus, the presence of the craftsmen was recorded in the city council, first as jury, then as magistrates and, finally, the artisans, together with the merchants and other citizens, formed a new patriciate that gradually took over the city government. Their number would continue to grow up, as the number of guilds, reaching eleven guilds in mid- $15^{\text {th }}$ century. Many guilds received royal grace, therefore, by the end of the $15^{\text {th }}$ century, the number of the guilds reached 20. This royal grace increased in Matthias Corvinus's time, a reign that was favourable to the development of the craftsmen and to their organisation. The $15^{\text {th }}$ century was important in the development of the handicrafts due to new emerged privileges that simplified the craftsmen life, due to the favourable reigns and due to the fact that the crafts continued to develop (there were new specialties and the techniques that leaded to increased production improved) (Pascu, 1974, pp. 105-106). Among the privileges from the $15^{\text {th }}$ century is the one from 1405, when the city obtained "the right to be surrounded by walls provided with bastions" (Pascu, 1969, p. 22).

During that time (the Middle Ages), the second fortification of Cluj was built, which is a "proof of the flourishing period of medieval Cluj, considered one of the main cities of Transylvania" (Bolog, 2016, p. 64). The name of "The Fortress of Guilds" comes from "the guilds (established in the $15^{\text {th }}$ century, when the Emperor Sigismund of Luxembourg granted Cluj with the status of free royal city, generating the right to build fortifications)" (Bolog, 2016, p. 64). Today, from "the old medieval fortress, whose construction lasted about 200 years, which had 20 towers and gates and was lying on 45 hectares", we are counting only "a few bastions, towers and fragments of walls: segments of the longest sides of West and South of the city, the Tailors' Tower (built in 1475 for defending the South-Eastern corner of the medieval fortress and considered the most important, and the strongest because it was the most exposed), the Tanners'/Shoemakers' Tower (after the name of the two guilds who built it and took care of it in the $15^{\text {th }}$ and $16^{\text {th }}$ centuries, the second bastion as size and importance, defending the South Western corner of the city), the Drapers' Tower (built in the $16^{\text {th }}$ century) the Fire Tower (later Locksmiths' Tower, built in 1574, originally called "the small gate in the Soap Lane"), The Old Fortress Tower (that became the Prison Tower, the most feared prison in Cluj [...], until the $19^{\text {th }}$ century)" (Bolog, 2016, p. 64).

The first two decades of the $16^{\text {th }}$ century are favourable for guilds' organisations, reaching in the mid- $16^{\text {th }}$ century, fifty branches and thirty guilds. However, due to increasing "population needs, new crafts appeared, among which: print shops, bindery books, the craft of musical instruments" (Pascu \& Marica, 1969, p. 25). Therefore, "The development of Cluj in the $16^{\text {th }}$ century would give it an authentic handicraft character. Dozens of guilds with hundreds of members, hundreds of artisans not enrolled in guild systems constituted the force of the city" (Goldenberg, 1958, p. 43). 
In the first half of the $18^{\text {th }}$ century, there were certified 25 guilds. Between 1750 and 1848 , there was a population growth which considerably increased the demand for major consumer items. As it became difficult that the demand be satisfied by local craftsmen, foreign traders took advantage of this situation, bringing various foreign products on the local market. There was a decrease in interest in handicraft, which triggered craftsmen's concern (Pascu, 1974, pp. 201202). So, 1872 brought a major change: the abolition of guilds and their transformation into craft cooperatives, on the basis of better technical production conditions: "guild regulation was disbanded just because the dynamics of capitalist enterprises, with their technical development and huge possibilities for economic expansion does not fit into the narrow frameworks created by the guild system regulating the production and sale" (Poleasnski, 1952, quoted by Goldenberg, 1958, p. 172).

\section{Craft: apprentices, journeymen and craftsmen}

To obtain the status of craftsman, a person had to undergo several steps to achieve this goal. According to the study of Pascu, The Crafts in Transylvania until the $16^{\text {th }}$ Century, there were two steps required to become craftsman, member of a guild: apprenticeship and journeyman (1954, pp. 263-295). The author affirmed that there were a number of conditions for receiving young people as apprenticeships: to be male, to be born into a legitimate marriage, to be Catholic and, in some guilds, they were not accepted as apprentices if they learned before another craft or if their parents practiced a lower qualified job.

Usually, the child chose to practice a family craft because of these two advantages: learning the craft from childhood, father's legacy and influence. The boys were accepted as apprentices when they were 10-12 years old (Pascu, 1954, p. 267). Another paper mentions that "young boys aged 14-15 years old [...] should be provided a trial period from two to four weeks, and if in the end of this period they were capable for the job, they were received as apprentices" (Crafts and Craftsmen from Nowadays Cluj, 2012, p. 3). Regarding the years of apprenticeship, there were differences "in time, in function of the difficulty of the craft. At the beginning, the years of apprenticeship were fewer, but the duration increased [...]. In general, apprenticeship was between three to five years" (Pascu, 1954, p. 267).

Other conditions imposed to apprentices are mentioned by the same historian, Pascu (1954, pp. 267-270): once accepted as apprentices, the younger had to accomplish a number of conditions, starting with the payment of a fee (in cash and in nature). In time, these taxes increased as a proof of the evidence that the guilds tried to limit the number of craftsman in order to prevent more young people to learn the craft and to became a competition for the existing ones. Then, once entered under the authority of a craftsman, the apprentice had to receive from him accomodation, food and clothes, education and the learning of the respective craft. The apprentice had to listen to and to respect the craftsman and the craftsman was not allowed to put him in other kind of works. However, this was not respected and the disciple was often put to "pull their boots, to wash their feet every Saturday evening, to brush clothes. Every Saturday they had to clean the working table of the craftsman and of journeymen, gather the tools, to know, when requested, from where to take it. [...] to bring water, to chop wood, to clean the house and the yard, etc." (Pascu, 1954, p. 268). The apprentice could not change his master during the apprenticeship, unless he had serious and proven reasons: if he was beaten, if he was borrowed by other craftsmen, if the master did not teach him his craft. On the craftman's death, the apprentice was assigned to another one. At the end of the apprenticeship, they received a certificate for being a journeyman (Pascu, 1954, pp. 269-270). 
"Being received among journeymen was marked off in a pretentious ceremony with a meal called a glass of companionship, with the participation of the craftsmen and journeymen, part of the same guild" (Crafts and Craftsmen from Nowadays Cluj, 2012, p. 3). According to Pascu (1954, pp. 271-287), the period of being a journeyman was from two to four years, during which, after being under the authority of the new master, the craftsman had to provide accomodation and meal, and the journeyman was compelled not to leave the craftsman without good reason. If, after a quarrel, the journeyman was separated from his master, he could no longer be employed by another master until coming to terms with his former master. Also, a craftsman was not allowed to receive a journeyman at odds with his former master. The journeyman had to behave properly with all the females of the craftsman familly, he was not allowed to go to pubs, he had to comply with the rules of the craftsman's house, he should spend his time only with honest women, he was not allowed to play games and he was not allowed to hang out or to wander around. If for 2 days a week he did not work, the journeyman lost the money for the entire week. If on Monday, they did not work, the journeymen remained without the salary for that week, being forced to work the whole week. The salary was small, and the workday was very long; often there were complaints on this issue.

"At the end of this period, the journeyman had to present to the guild leaders his birth certificate, the certificate of apprenticeship, the certificate of morality, and whether they were considered appropriate, the journeyman was declared a citizen and he could participate at his exam for becoming a craftsman. The exam consisted of a practical work, a masterpiece or a craftsmanship" (Crafts and Craftsmen from Nowadays Cluj, 2012, pp. 3-4). "The work of craftsmanship was chosen for two reasons [...]. Firstly, to make more difficult the access of new members in the guild, through the circumstances in which such works had to be carried out [...], secondly, a technical control took place, a control on the training of the journeyman" (Goldenberg, 1958, p. 191).

\section{The current situation in Cluj-Napoca}

\subsection{Craft associations in Cluj County}

Craft associations could be considered descendands of the medieval guilds, even if these associations group not only craftsmen practicing one craft or more related crafts, but also they are organisations that comprise all the craftsmen and producers of traditional crafts. In Cluj-Napoca, there were identified three such associations: Breasla Meșteșugarilor din Transilvania [The Craftsmen's Guild from Transylvania] (http://craftsmen.ro/index.php/ro/), Asociația Meșterilor Populari Clujeni [The Cluj Craftsmen's Association] (Crafts and Craftsmen from Nowadays Cluj, 2012) and Asociația Produs de Cluj [The Association Made in Cluj] (http://www.produsdecluj.ro/). Each of these associations aims at the same goals: to promote and to support the development of traditional crafts, so that these ancient occupations will survive, to identify individuals who practice crafts and traditional occupations and to support them during production and marketing, to organise fairs, festivals, and events in the country and abroad.

Another important objective is to integrate the traditional crafts associations into tourism, trying to include the traditions into the international tourist circulation, detemining visitors become potential buyers. This way, the impact is both cultural and economic: on the one hand, the effort to preserve the Romanian traditions and crafts, to learn and to train young people in crafting and to raise the awareness on this topic, and, on the other hand, it is considered the economic impact, whether craftsmen are able to create income just by practicing the craft and selling final 
products to tourists, and also by creating workshops included in tour packages, for discovering the secrets of crafting.

\subsubsection{Professional qualification and certification as craftsman}

If the certification as a craftsman in the Middle Ages was taking a long time and the criteria were clear, undergoing first oapprenticeship and then the journeyman activity, finishing with the certification as craftsman, obtained after making a work of craftsmanship, examined by a committee of members of that guild, nowadays, there is no national system of evaluation and certification of craftsmen.

Professional qualification is achieved after finishing qualification courses organised by various institutions (ANOFM - Agenția Națională pentru Ocuparea Forței de Muncă [National Agency for Employment], AJOFM - Agenția Județeană pentru Ocuparea Forței de Muncă [County Agency for Employment]), by different training centres or through European funds financed projects; participants may get accredited certificates from the National Authority for Qualifications. Such a project of qualification in the handicrafts is the Workshop for Crafts (http://atelieruldemestesuguri.worldvision.ro/nv/despre-proiect). Another way to get a professional qualification for crafts, included in the Classification of Occupations in Romania (some crafts ranging in the group 731 - skilled workers in manufacturing products), is through apprenticeship at work, regulated by Law no. 279/05.10.2005, regarding apprenticeship at work, aiming at practical and theoretical training and evaluation of a disciple in a certified craft existing in COR - Clasificarea Ocupațiilor din România [Classification of Occupations in Romania].

Certification as an artisan is the responsibility of the County Cultural Centre. Attestation is usually taking into account criteria such as: technical work, respect for the popular tradition, theoretical knowledge, and complexity of the created objects. The evaluation is performed, in general, by ethnographs, curators, and restorers.

The certificate of artisan can be obtained, also, after registration in an association. Of course, the situation varies from one association to another. For example, the entry in the Association of Craftsmen from Cluj, according to the President of the Association, Viorica Ciobanu is the following: "the newly registred person must sustain a practical test supervised by a member of the guild, then the member will draw a report, following a period of practice of 3 months during which the new member will participate in a fair, and then, if everything goes right, the new member will be received in the association and will obtain the certificate of craftsman".

\subsubsection{Craftsmen's characteristics}

We will try to outline several important features of craftsmen in Cluj-Napoca by analysing thirty craftsmen's answers to a questionnaire. They were part of the Association of Craftsmen from Cluj, which today counts 160 craftsmen (http://www.iartterritories.com/ro/companii/romania/asociaia-meterilor-populariclujeni/id/36). The analysis of their answers revealed the following characteristics:

a) according to the practiced craft: first is tailoring (sewing, weaving, crocheting); on the second place are jewelery, painting and leather processing, and the third position is occupied by woodworking, the last being ceramics, felting wool, and quilling (Figure 1-left);

b) according to their age: the adult population is the predominant group ), followed by the elderly population; the young age group is missing (Figure 1 - right). 

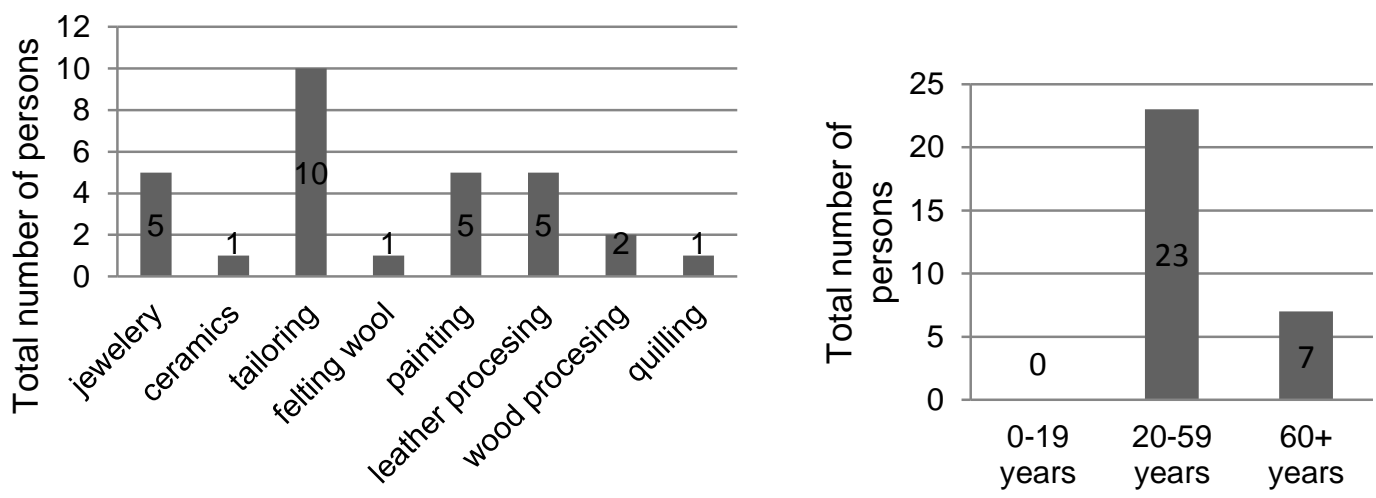

Figure 1: Craftsmen's distribution according to their craft (left) and by age (right)

Source: Respondents' answers to the questionnaire, 2016, Raluca Georgiana Brie

c) according to their experience in the practiced craft: the majority of craftsmen (60\%) have between 1 and 10 years of experience, only $10 \%$ having $11-20$ years of experience, $13 \%$ had 21 30 years experience, $10 \%$ having experience of $31-40$, etc. (Figure $2-$ left).

d) in terms of occupational distribution, the situation is as follows: the highest percentage, $60 \%$, is held by the employee category, $30 \%$ were pensioners, and $7 \%$ said they were household workers (Figure 2 - right).
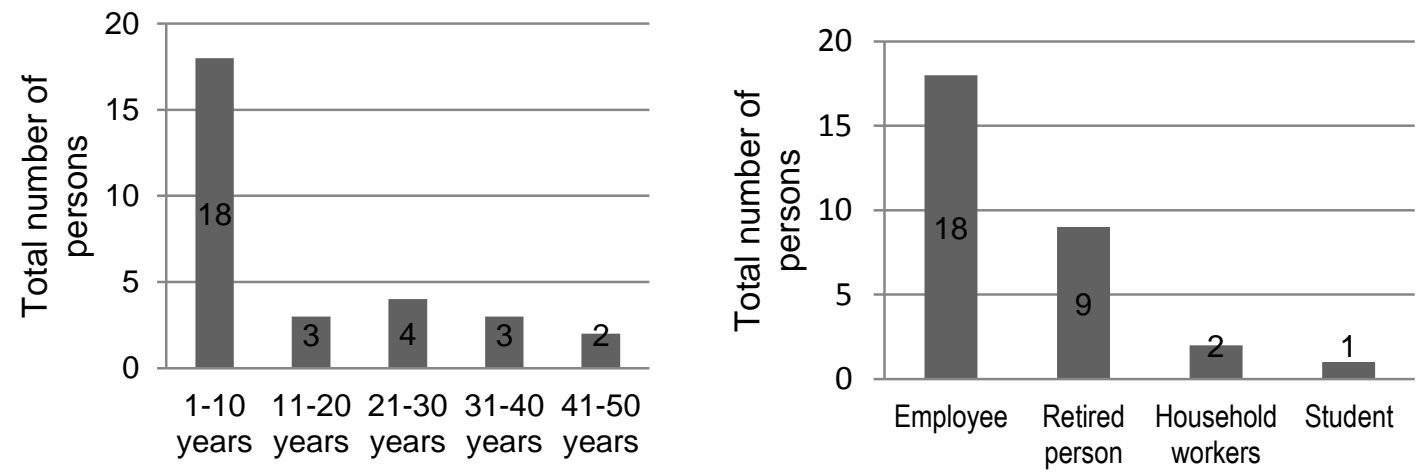

Figure 2: Craftsmen's distribution according to their experience (left) and by activity (right)

Source: Respondents' answers to the questionnaire, 2016, Raluca Georgiana Brie

e) according to their level of education: almost $50 \%$ gratuated university studies, $40 \%$ completed high school and $10 \%$ completed a vocational school, thus resultinga medium to higher education level; there are no people with a lower level of education than high school (Figure 3 - left).

f) learning the craft: family and school are on the same level, (33\%-34\%). It is also significant the percentage of those who learned the craft by themselves (30\%), and only one person learned the craft from friends (Figure 3 - right). Every surveyed person belongs to the Association of Craftsmen from Cluj, association whose role is the attestation of craftsmen; so we can conclude that the craftsmen who had not been trained in the formal or institutional system acquired the craftsman certificate after entering into this association and passed the necessary practical tests, performed in front of a craftsman, member of the association. 

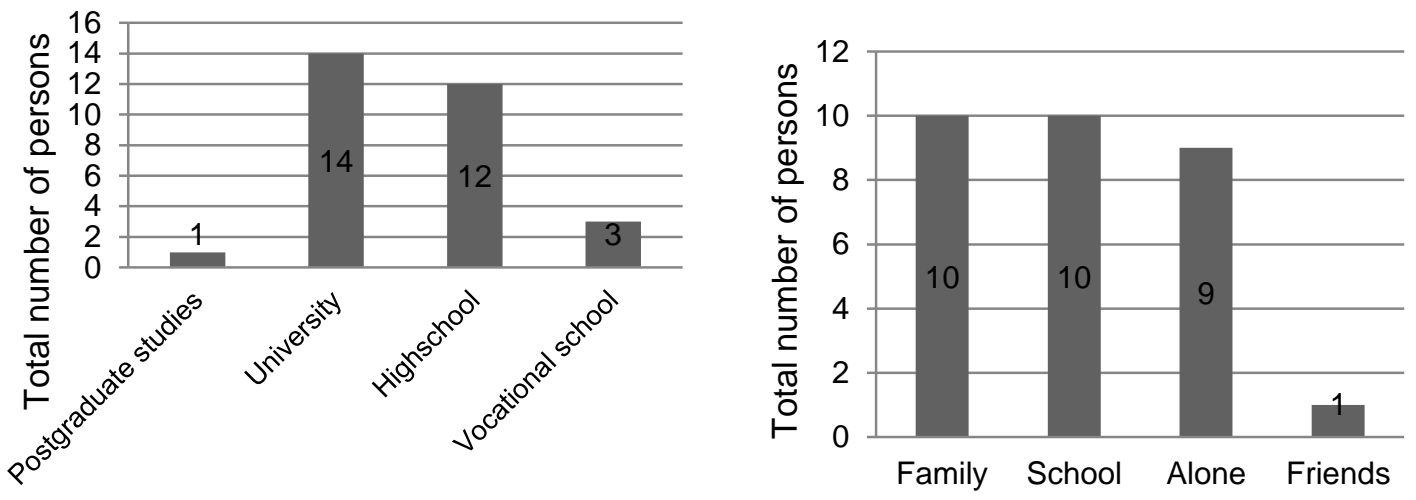

Figure 3: Craftsmen's distribution by level of education (left) and by craft learning (right) Source: Respondents' answers to the questionnaire, 2016, Raluca Georgiana Brie

g) purpose of practicing the craft: more than half (60\%) practice the craft to obtain additional income, while the others practice the craft as a hobby or as an occupation (20\% each) (Figure 4 - left).

h) owning a workshop: $67 \%$ own a workshop, and $33 \%$ of craftsmen do not (Figure 4 - right). Of the 20 craftsmen who own workshops, only four can be visited, there is no visit tax and no fixed schedule (visits could be done only by appointment).
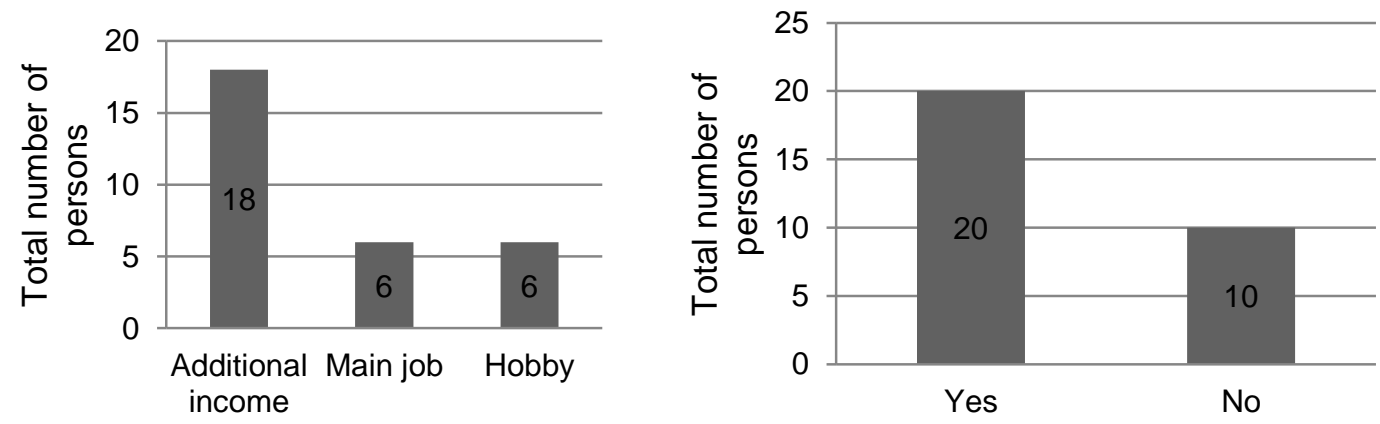

Figure 4: Craftsmen's distribution by the purpose of practicing the craft (left) and by owning a workshop (right)

Source: Respondents' answers to the questionnaire, 2016, Raluca Georgiana Brie

\section{Comparative analysis of craft fairs held in Cluj-Napoca}

Fairs, perhaps the most popular events associated to crafts, are an anthropic tourist resource, representing the "temporary polarising centres (from one day to several weeks) of commercial activities or exhibitions" (Cocean \& Dezsi, 2009, p. 147). During the fairs, craftsmen bring up traditional objects or those ispired from tradition, which they made with great care.

The fairs are organised mostly during religious holidays or important events. Thus, over the year, in the proximity of these celebrations, the city catches colour in its old markets, supermarkets, 
along the streets with medieval flavour, in parks or in any other location that may be adapted in order to permit the development of a commercial fair, where the offer meets the demand.

We analysed five major craft fairs held in Cluj-Napoca in the period December 2015 - May 2016: The Christmas Fair (December the $1^{\text {st }} 2015$ - January the 10 10 2016), the "Mărţişor" (a Romanian celebration at the beginning of spring, when red and white strings with a hanging tassel are customarily given on the $1^{\text {st }}$ day of March) Fair and the $8^{\text {th }}$ of March Fair (February $24^{\text {th }}$ to March $\left.9^{\text {th }}, 2016\right)$, the Catholic Easter Fair and the Orthodox Easter Fair.

\subsection{Similarities and differences}

\subsubsection{Motivation and duration}

Fairs are generated by various occasions and events, based generally on religious holidays hosting the purchase of food and non-food products. Also, fairs gather lots of people at generated or auto-generated activities, usually at the local level.

The most extended period of a fair in Cluj-Napoca is the one dedicated to the Feast of the Nativity, lasting over 41 days (December the $1^{\text {st }} 2015$ - January the $10^{\text {th }} 2016$ ), thus including several dates that are a shopping opportunity with local and tourism interest. Therefore, under the name of the Christmas Fair, there are covered, in fact, at least six occasions to celebrate: the National Day of Romania ( the $1^{\text {st }}$ of December); Saint Nicholas, as an opportunity to purchase and give presents (December the $6^{\text {th }}$ ); the Feast of the Nativity with its Santa associate and the opportunity to give presents and to cook traditional food; the Feast of New Year's Eve, with a suite of shopping related, and even the Saint Basil the Great (January the $1^{\text {st }}$ ) and John the Baptist (January the $7^{\text {th }}$ ), feasts celebrating names quite common in the national onomastology, giving occasions for party.

A similar, but not so complex, situation is during the fair organised on the occasion of the $1^{\text {st }}$ of March, "Mărţişor", when, under the slogan "Cluj is always smiling for Dragobete (Romanian Valentine's Day) and Mărţişor", there are put together both traditional feasts and the fair continues with the one dedicated to the International Women's Day.

As a rule, other fairs are conducted during a week (7-9 days) and include some previous days before the occasion and end, usually, the day after the event that occasioned its organisation.

\subsubsection{Location}

The preferred location is one of the four central squares of the city, the Union Square, where four of the analysed fairs took place. This location is, in fact, the main area of events in the city. The exception is the Fair on March the $8^{\text {th }}$, held in the Avram lancu Square. Both locations generate streams of potential buyers, both local people (in the two squares there are the most important churches) and tourists (usually the Union Square or the area adjacent represent places of embarkation/disembarkation for tourists and guided tours begin or end mostly in the Union Square or in the Avram lancu Square).

\subsubsection{Organisers}

All fairs are organised by the Municipality and the Local Council Cluj-Napoca, in collaboration with the Association of Craftsmen from Cluj, and, for the Catholic Easter, also by the 
Transylvanian Craftsmen Guild Association. This information was obtained in the field, from the organisers, from the official website of Cluj-Napoca City Hall (www.primariaclujnapoca.ro) and from the information panels within the fairs.

\subsubsection{Number of participants (booths)}

Within the 5 events/fairs held during the six reviewed months, there were quantified 319 booths of manufacturers, craftsmen, artisans and traders ( 42 booths at the Christmas Market, 100 booths at the "Mărțișor" Fair, 30 booths at the $8^{\text {th }}$ of March Fair, 57 booths at the Catholic Easter Fair, 90 booths at the Orthodox Easter Fair), with the following distribution by major types of products: 241 non-food booths and 78 booths with food (Figure 5). According to their distribution, the highest percentage of non-food items was at the "Mărțișor" Fair (20\%), at the opposite pole being the Christmas Fair (45\%). The percentages were according to the type of event that occasioned the organisation of the fair and the activities generated by it. All the booths were counted on the spot, in the absence of official sources confirming the number of participants.

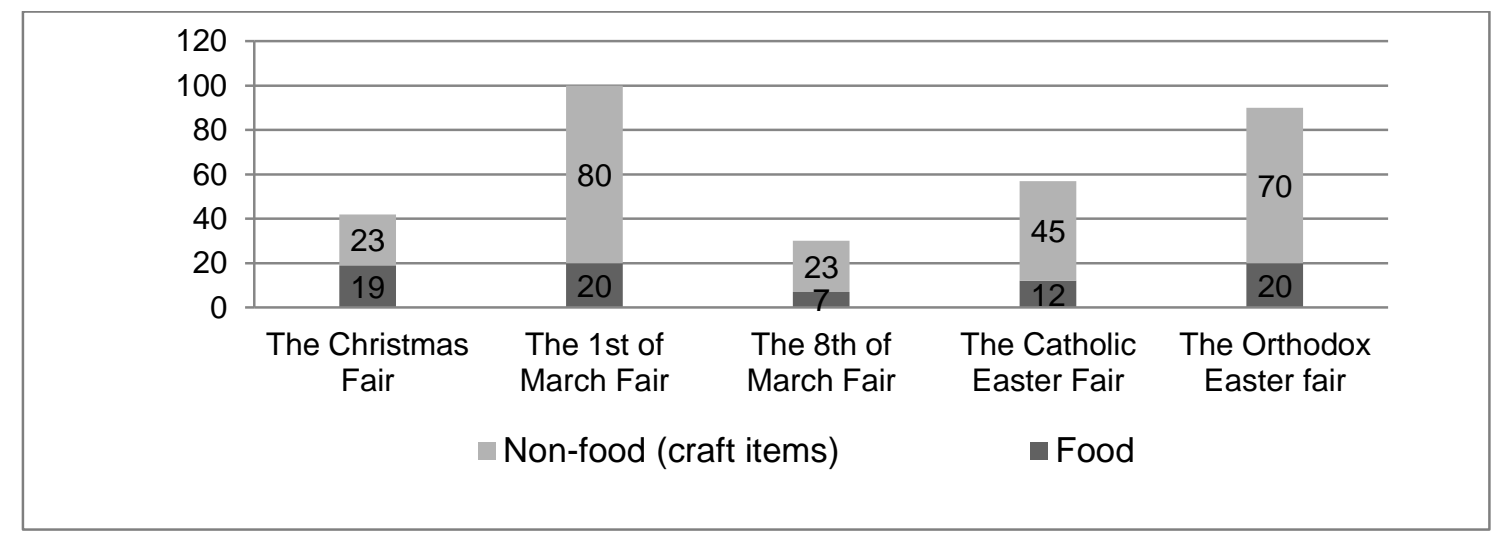

Figure 5: Number of booths/booths that sell food products and non-food products

Source: Brie \& Bolog's counting, 2015-2016

\subsection{Authenticity versus kitsch at the fairs}

\subsubsection{Defining features of authenticity}

The term "authenticity" is derived from the adjective authentic and it is "a fact or the attribute of being authentic" (https://dexonline.ro/definitie/autenticitate). This term generally has positive connotations, such as: honesty, truth, fairness, and morality.

According to Rață et al. (2012, pp. 107-111), the concept of authenticity is rooted in the existential philosophy, extended then to other areas, such as ethics, existentialism, historical reenactment, philosophy of art, psychology, etc. The same authors define authenticity as "the quality of being genuine, non-corrupted from the original, with thrue origins, attributes, commitments, andintentions" (Rață et al., 2012, p. 108). These authors also mention that authenticity is one of the defining characteristics that cannot be deciphered for an object only at a glance. To determine whether an object is genuine or not, one needs additional information. Authenticity affects the value, meaning, and interpretation, the people's acceptance or response to objects. Authenticity cannot be reproduced: "even the most perfect reproduction 
of a work of art lacks a basic element: its presence in time and space, its unique existence at the place to be" (Rață et al., 2012, pp. 107-109).

As cited by Rață et al. (2012, p. 111), Sathe (2003) defines authenticity and inauthenticity as "imaginary constructions that are affixed as attributes of objects, people or practices". Le Petit Larousse (2006, p. 124) defines authentic in a very simple manner, "whose exactity, origin, assignment are incontestable" and "with a total sincerity". If we return to tourism, "authenticity is conceived as a negotiable rather than primitive concept, the rigor of its definition by subjects depending on the mode of their aspired touristic experience" (Cohen, 1988, p. 371), referring, in our case, both to the experience of interaction between craftsmen and tourist, tourist and object and handicraft experience itself.

\subsubsection{Kitsch and its features}

Erosion of cultural traditions in the marketing of products is one of the current concerns in research development and in academic research (Littrell \& Dickson, 1999). The emergence of kitsch is closely related to the modern period, when the industrial revolution created the necessary means for smoothig the process of multiplying products and objects, when man, from the perspective of a creator, began to be replaced by the man who produced or reproduced, on a large-scale,the existing creations. In his study Kitsch Psychology, Abraham Moles states that the term comes from the German language being used for the first time in Munich in 1860; kitschen means to do something superficially and verkitschen to degrade, to crumble, to maim (Moles, 1980, p. 49).

Starting from the definition extarcted from The Explanatory Dictionary of the Romanian Language (2009), kitsch is a "term used to describe a gaudy decoration object" or "a reproduction or copying, on industrial scale, of a work of art, multiplied and used with commercial end" (https://dexonline.ro/definitie/kitsch). Continuing with the definition from The Dictionary of General Aesthetic (quoted by Daj \& Stareţu, 2009, p. 67), "kitsch is an untranslatable German word, entered as such between the international terms of aesthetics and art, used to describe tacky, pseudo-art and all those aesthetic products designed for the exploitation of a limited group of stimuli or of only one stimulus that form the art: biological, ethical, magical, or ludic determined".

Also, if we refer to definitions in other languages, according to Larousse Dictionary (2006, p. 614), the definition is simple: kitsch is "an object, a landscape, a work of art whose gaudy, even vulgarity, intentional or not, gives pleasure to some, rejects the others". Moreover, "the great psychological discovery underlying kitsch is that almost anything related directly or indirectly to the artistic culture can be transformed into an object for immediate consumption, like any other ordinary goods" (Călinescu, 2005, p. 239). We conclude with the idea that the term kitsch has a negative connotation, being used to describe bad taste or poorly made things.

It originally appeared in the world of art as pseudo-art. Nowadays, kitsch seems to capture increasingly more areas: music, architecture, sculpture, literature, and objects. The kitsch misses the creator's personal influences or the consumer's preferences. The kitsch assumes an acceptance from the majority, so that the same product is trying to please as many people as possible.

If true art requires consumer's effort to understand its mysteries, the kitsch imitates the reality in a way more affordable adopted by a large majority, the intellectual effort for understanding and appreciating being limited or minimum. Exploitation of symbols through consumer items leads to the vulgarisation of both the object itself, and the symbol. In this sense, we recall, as 
example, the situation in which the symbol of the Christian faith, the crucifix, is attached to a keychain or to a watch, none of these objects having connections with the crucifix.

Another important feature of the kitsch design is disproportioning of kitsch objects dimensions which are not created according to the actual size of the original object: "gigantification or miniaturization represent classical features of kitsch objects, which reproduce only the recognizable form, not the concrete existential aspect of the object" (Moles, 1980, p. 49). Therefore, a pair of earrings in the form of a giant elephant or a mouse will be considered kitsch objects, original proportions are not respected and "the final result is only an unrepresentative imitation of the reality, which leads us to another feature of this style: imitating the reality or the reality effects, produced through the sensory experiences that we live, leads to artificial emotions" (Moles, 1980, p. 49).

Kitsch does not examine the culture, but it stylises and reinterprets it, using the dilution of the originality to make it acceptable to all. Therefore, kitsch objects are not rationally justifying their role, they are only an attempt to satisfy and to appeal a larger number of consumers. Hence, due to its position within mass production, kitsch is an "art" accepted by the majority and created by and for ordinary people.

The trade character is representative, kitsch becoming a powerful industry. Cheap and affordable products are real substitutes for genuine products. Reproduction as cheap serial products is sometimes much easily accepted due to consumer's cultural and/or aesthetic education or due to economic reasons.

Rich ornamentation, sometimes excessive, or the existence of minimalist elements are kitsch features, along with the imitation of materials to create a false perception of the product, or the use of contrasting colours. In addition, "regardless of its origin, kitsch was and still is a strong pejorative word and therefore lends itself to a wide range of subjective uses. To call something kitsch means, in most cases, a way to reject it from the very beginning as distasteful, repugnant or even disgusting" (Călinescu, 2005, p. 229).

\subsubsection{Analysis of authenticity within the craftsmen's fairs in Cluj-Napoca}

\subsubsection{Analysis of manufacturers' and traders' booths}

In the Christmas Fair, the booths are diversified, but the majority contain objects or products from several categories (jewelry and textiles, wooden objects and textiles, etc.), while specialised booths in one product category are much less numerous.

From the 19 booths with food, the best represented were the sweets (kurtos kalacs/Seckler cake, cakes, chocolates, pastries and other sweets, pancakes, and gingerbread), followed by meat products and hot drinks, roasted chestnuts and dairy products, fruits, syrups, and honey.

Regarding non-food products, therefore products sold by craftsmen and artisans, they occupied less than half of all the existing booths. The highest percentage was occupied by jewelry: traditional beads, leather, wood, wooden beads, precious stones, metal beads, and pottery.

On the same place with jewels, there stood household textiles and clothing (we fit here all woven products, sewn, crocheted, embroidered, and leather and fur clothing items, and all the rest of the textile products). In the category of these products, there were: table cloths and napkins, quilts, leather or fur hats, crocheted blouses, waistcoats, bow ties, scarves, woolen homemade bags and shoes. 
Another important product category was represente by wooden objects, mostly with decorative function: toys, clocks and music boxes, jewelry boxes, sculptures, and other decorative items. Regarding wooden objects with utility functions there was only one booth.

It is worth mentioning that the objects dedicated to Christmas were very badly represented: only 4 booths $(10 \%)$ were selling products dedicated to this event. During the fair, there were also paintings, decorative candles, pottery, plush toys, magnets, crocheted toys, dolls dressed in traditional clothing, bow ties, key rings, all with kitsch features (Figure 6).

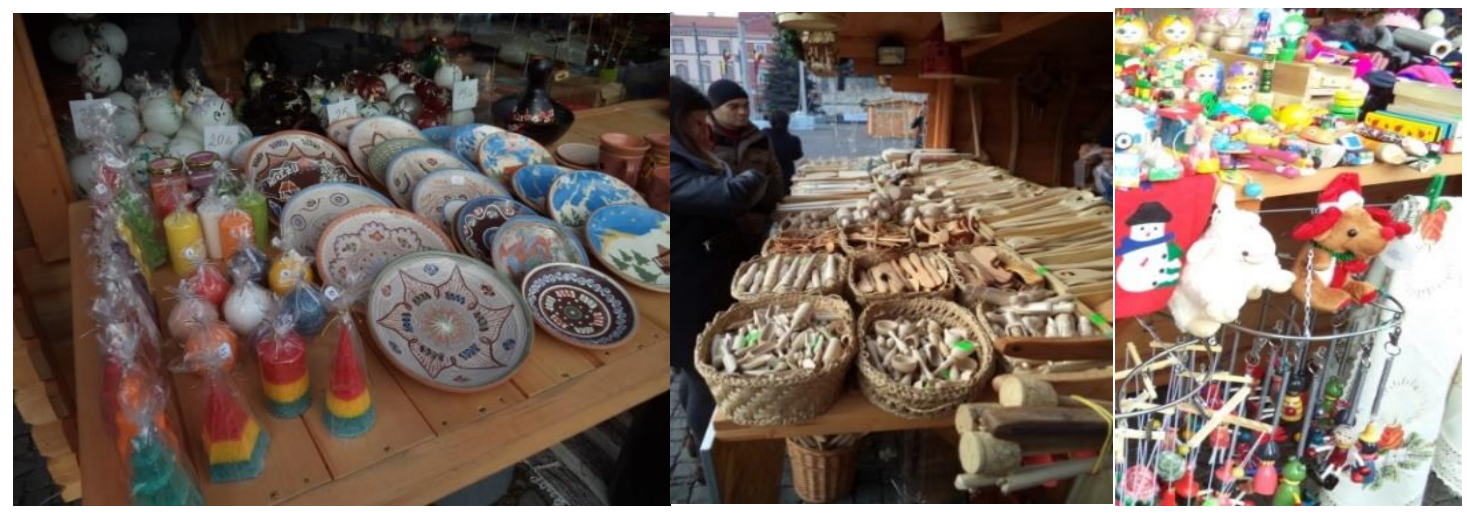

Figure 6: Ceramic plates and candles (left), wooden spoons (middle), wooden and plush toys (right) Photos by Raluca Georgiana Brie, 2015, The Christmas Fair

The "Mărţişor" Fair brought together a wide range of these objects named "mărțișor", authentic from the point of view of the traditional techniques and the materials used, most of them being hand-made (Figure 7). The wide range of the traditional objects named "mărțișoare", was complemented by other products such as: jewelry, stone sculptures, lavender, greeting cards, brooches, dolls, flower decorations, and glass objects. The traditional objects named "mărțișoare", were made out of ceramics, felt, paper, beads, fimo-plasticine, pressed flowers and plants, wood, etc. Among the famous symbols, there were horseshoes, four-leaf clovers, snowdrops, but also a series of animated characters for the children, unrelated to the symbolism.

Noteworthy is the spirit of authenticity of these objects, with unique value and the use of traditional techniques, as well as fashionable (in the current trend of hand-made) techniques as frivolite and quilling techniques, with hand paintings and traditional decorations, or those made from fimo-plasticine or beads also with great aesthetic appeal and authentic features.

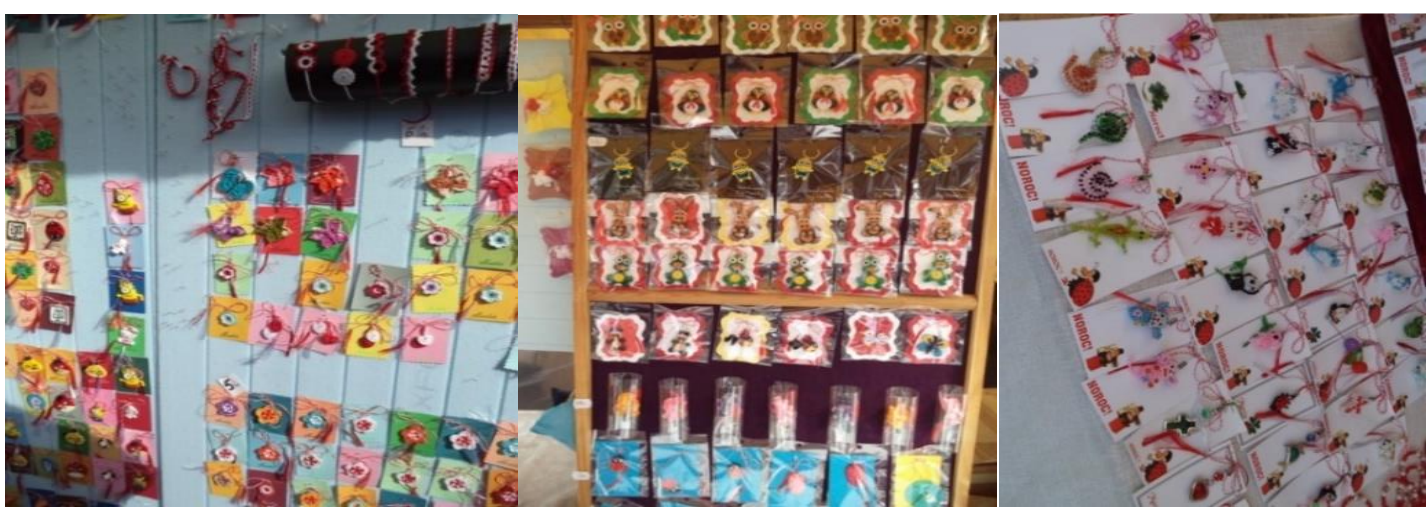

Figure 7: Crocheted trinket - frivolite (left), paper-quilling (middle), and beads technique (right) Photos by Raluca Georgiana Brie, 2016, The "Mărțișor" Fair 
Even if it lasted less, the fair organised on the occasion of the $8^{\text {th }}$ of March (The International Women's Day), managed to bring together more than 30 manufacturers, craftsmen, artisans and merchants. Out of the 30 booths that were present, seven were specialised in food products: meat products, wine, jams, honey and bee products, cakes and other sweets, sunflower oil, gingerbread and syrups, medicinal teas and tinctures. Regarding non-food products, jewels occupied the first place (11 booths out of the 23 non-food ones). In this case, the jewels were extremely diverse: from traditional beads, ceramic decorated, with pressed flowers, wood, crochet, glass, pearls, crochet with beads or just simple necklaces or nontraditional bracelets made of beads. On the second place, there were the products of household textiles and clothing: uppers and napkins, blankets, blouses, crocheted coats, homemade woolen shoes and handbags and other leather accessories, handbags, woven bags made of velvet embroidered with beads. Wooden toys were also present in three booths, and there were also flower decorations of dried flowers or lavender (three booths). The pictures painted in oil on canvas or glass icons were from two booths, and decorative glass objects on one booth. Decorative objects, obtained through the quilling technique, were on one booth, and also stone sculptures accompanied by the artisan work on the spot.

The Fair dedicated to the Catholic Easter grouped traditional products, crafts and handicrafts including 12 food and 45 non-food booths, so the products sold by artists and artisans were predominant. The sold food was: honey and bee products (five producers), jams and syrups, fruit (three producers), fruits and gingerbread (one booth), meat products and dairy (two booths), cakes and homemade chocolate (three booths). If food was underrepresented, nonfood products were extremely varied, occupying 45 of the present 57 booths. It is worth mentioning that these products were more diverse than in the previous analysed fairs.

If until now the jewels were the most numerous (except the Mărţişor Fair), in this fair, ornaments (jewelry beads, leather bracelets, metal jewelery, and precious stones) were presented only on nine booths. Numerous products were household textiles and clothing (13 booths), carpets and cloths made by wool, bags and accessories in leather, tablecloth and napkins, leather coats and hats, scarves, clothing items from the traditional costumes, crocheted handbags, velvet decorated with beads, and other textiles. Wooden objects occupied six booths, two of them with household products and wooden decorative items, all with strong aesthetic features. Less represented in previous cases, ceramics was present on five booths. Simple or painted ceramic products had household functions (plates, cups, and bowls) and decorative ones (flower pots and garden decorations).

We noted the dolls dressed in traditional clothes adorned with beads or puppets made of felt and the craft of making woven baskets that was present due to its products on four booths, and leather paintings or stone sculptures (including craftsmen's demonstrations). The Easter symbol, painted eggs or wodden painted eggs were only on two booths.

As usual, there were: flowers and dried flowers decorations, oil paintings or icons painted on glass or wood, glass objects, objects made through quilling (the craft of rolling paper), knives in leather sheath, natural soap bars, magnets with kitsch features and no related to the event. 


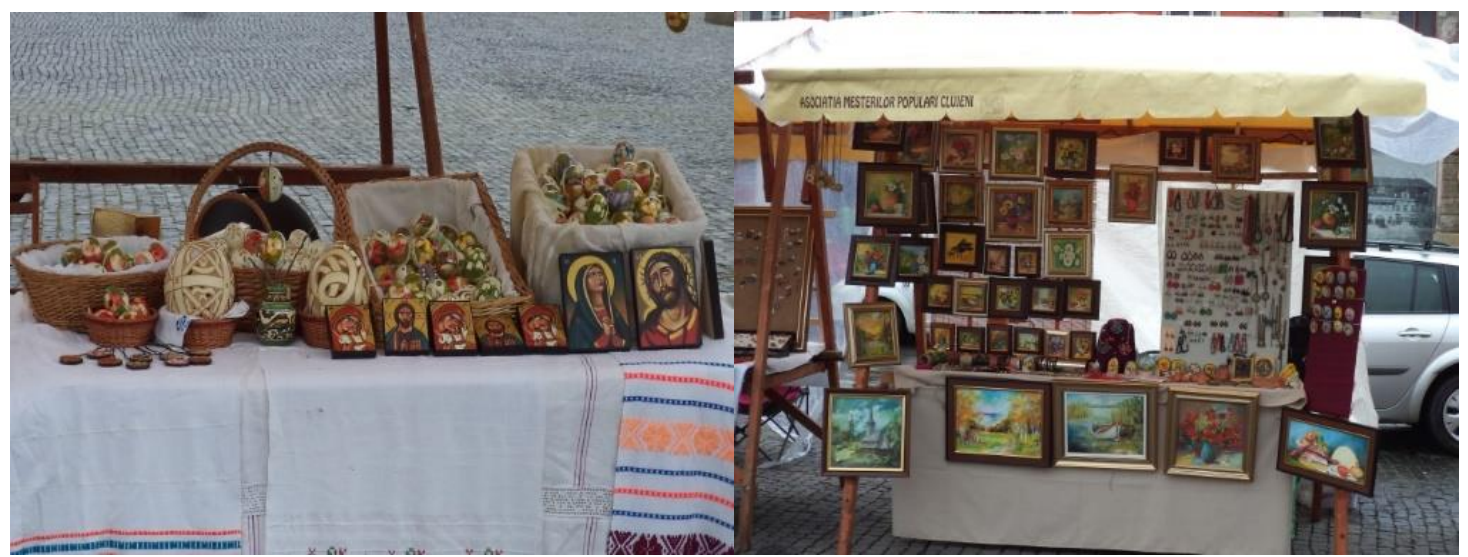

Figure 8: Painted and wooden eggs (left) and traditional painted icons (right)

Photos by Raluca Georgiana Brie, 2016, The Orthodox Easter Fair

On the Orthodox Easter Fair, the food products were represented on $22 \%$ of the booths (only 20 out of the 90 booths), the rest of the booths hosting non-food products (Figure 8).

On the 20 booths with food products, we found: honey and other bee products (the best representation, on five booths), meat products, syrups, and sweets (e.g. cakes, halva, and gingerbread) on four booths each, and (on one booth), agricultural products (fruits), jams and dairy products.

Regarding the distribution of non-food products, again, jewels, although there is no connection with the symbolism of organising this fair, were best represented (30 booths): jewelry, ceramic, leather, beads, traditional jewelry such as bracelets, woven, metal jewelry, wooden jewelry, and precious stones jewelry.

The jewels were followed by household textiles and clothing ( 15 booths) and by traditional costumes, scarves, wool carpets and leather clothes, tablecloths and napkins, and crocheted clothing items (Figure 9).

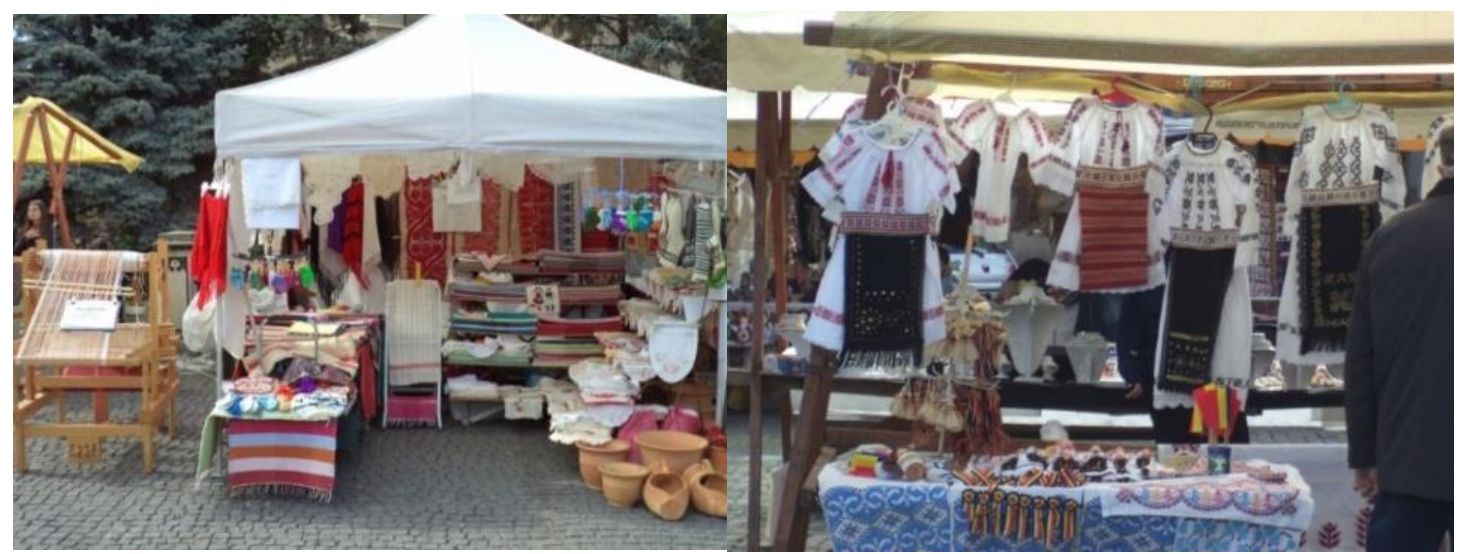

Figure 9: Woven textiles (left) and traditional clothes (right)

Photos by Raluca Georgiana Brie, 2016, The Orthodox Easter Fair 
Wood craft was present on eight booths, wooden objects having mostly a decorative role (e.g. vases, jewelry boxes, boxes, and other decorative items). There were also paintings and icons, oil paintings, paintings on wood and glass painting (seven booths). Noteworthy was the booth with carved paintings, made right in front of the viewers, and the icons on eggshell mosaic (Figure 10).

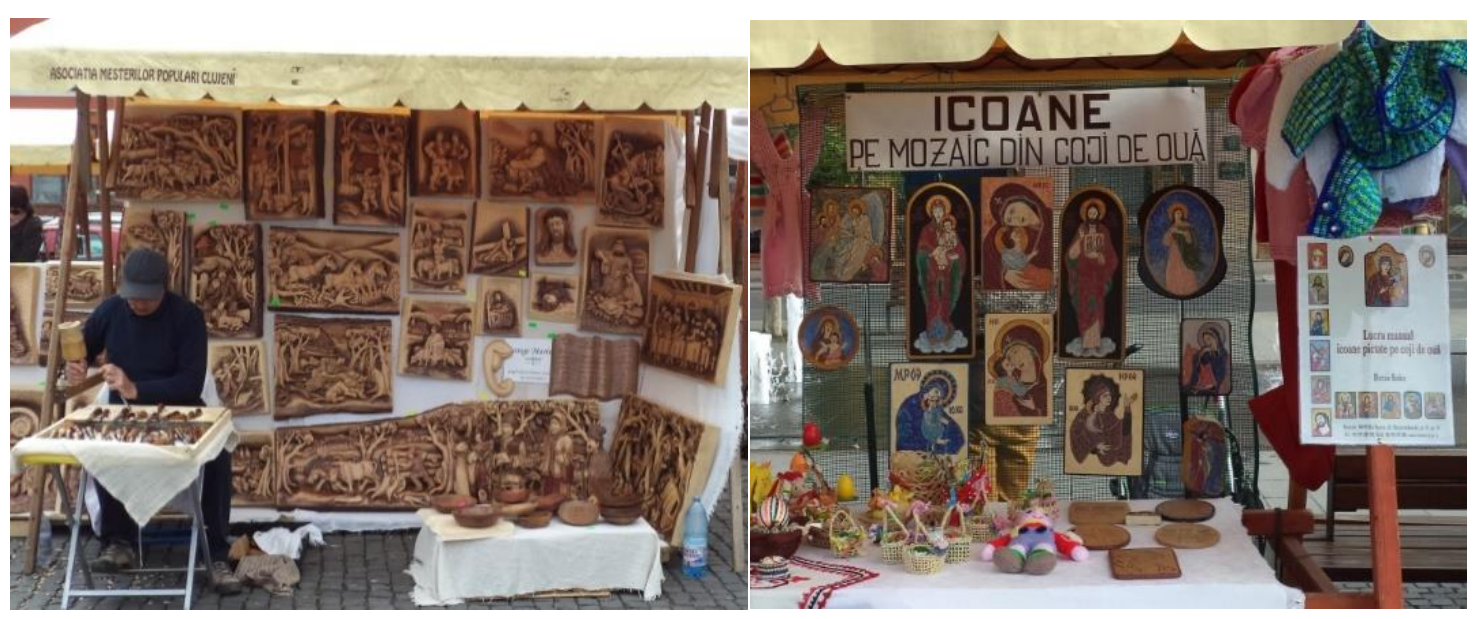

Figure 10: Carved painting (left) and eggshell mosaic icons (right)

Photos by Raluca Georgiana Brie, 2016, The Orthodox Easter Fair

Pottery was present at six booths, with plain or painted ceramic products, mostly with household functions (e.g. plates, cups) and decorative ones (e.g. garden decorations, pots, and vases). There were also handbags and accessories, such as: handbags, leather or woven handbags, leather belts, wallets and floral arrangements (three booths). There were fridge magnets on six booths, with the same kitsch features, but rated all over as a good souvenir. Wicker baskets were presented on two booths. For stimulating the buyers on the subject of the Rabbit arriving during the Easter time, there were gifts for children: toys (wooden and crocheted toys) on four booths. The symbol of Easter, the painted eggs, occupied four booths.

Other objects were less represented: decorative candles, stone sculptures, glass objects, decorative objects, crocheted traditional dolls, natural soap bars, lavender, musical instruments, many of them with non-authentic features.

\subsubsection{Authentic and non-authentic expression through handicraft products}

As mentioned in the methodology, all the booths present on the sites of the fairs, were analysed according to the attributes of authenticity and kitsch, and considering the types of exhibited products, the booth was characterised as authentic or not taking into account the number of dominant products.

As a kitsch is a strong pejorative word that attracts series of meanings, often subjective, the analysis of this aspect of the product has subjective connotations and could bear, also, different interpretations. Even kitsch definitions introduced, from the beginning, the problem of subjectivity, when referring to what kitsch produces: "joy" or "rejection" (Le Petit Larousse, 2006, p. 614), depending on the viewer and his or her education. "As we mentioned before, $M$. Călinescu underline that when assessing somethink as kitsch, we consider, in most cases, the way to reject it from the begining (Călinescu, 2005, p. 229). 
The results of the analysis based on the presented methodology confirmed the predominance of authenticity (Figure 11), except for the Fair dedicated to the symbol of spring, "Mărțișor", where the percentage of authentic objects did not exceed $40 \%$, in favour of the non-authentic or kitsch features. In general, the demarcation line remains very thin and the figures, in many cases, are close, placing the authentic/non-authentic in a delicate balance.

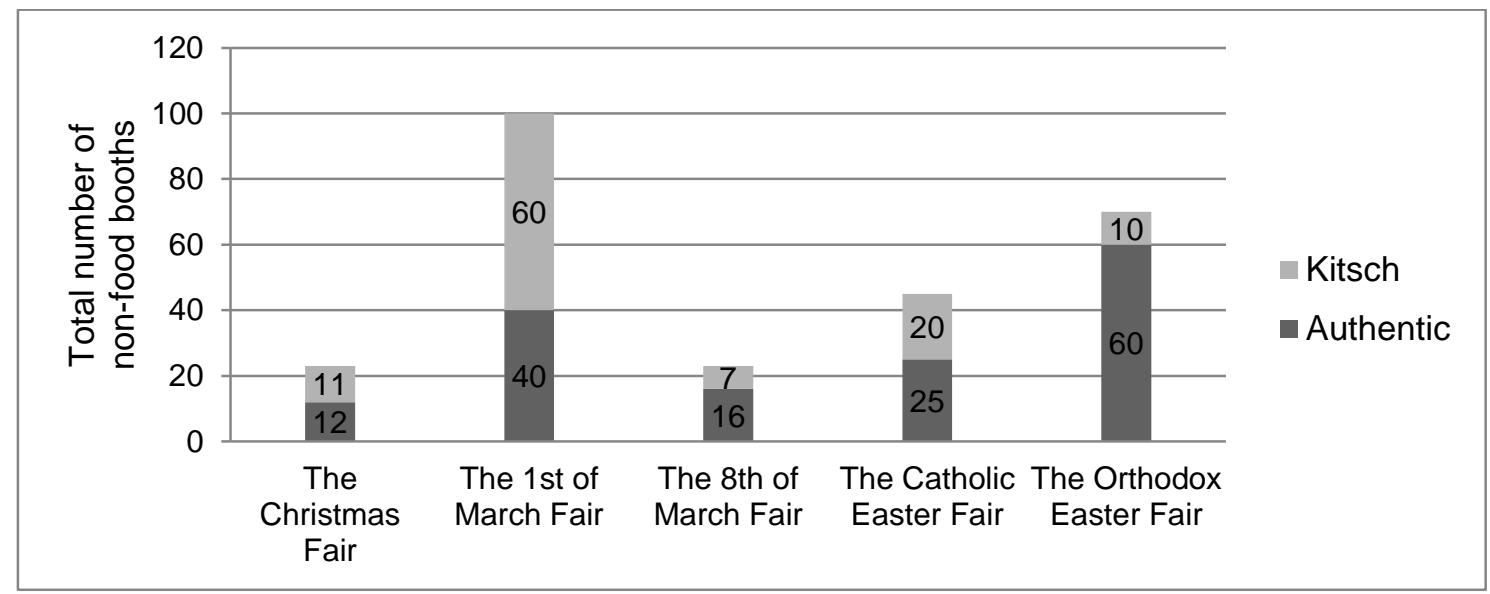

Figure 11: The number of booths selling authentic and non-authentic products

Source: Brie \& Bolog's counting, 2015-2016

\section{Tourism capitalisation of crafts in urban areas}

\subsection{Differences of capitalisation in rural and urban areas}

The used expression of "traditional crafts" points out to the Romanian village, to the deep rural in areas where tradition still exists or people are trying to keep it, to places where people still live by means of traditional agriculture, who are dressed traditionally during Sundays or holidays. But crafts were born not only in villages. They represented, in fact, an important component in the life of medieval cities. Even if they have lost significance or importance with the advent of the industry, these crafts have played an important role in the life of cities, thus developing and revitalising this role should take place not only in the rural areas, but also in urban ones. While in the urban areas, these crafts are designed to diversify the income sources, leading to the economic growth of the area, but also to preserving the old crafts, urban crafts can be seen as embodiments of leisure activities sharing and transmitting old crafts, through workshops, as well as through tourism. Most EU programmes provide funds for the development of the crafts in rural areas (usually they provide opportunities for skill and labour market integration of rural people and highlight the local identity and tradition). But uptake of such projects is also suitable for the urban environment with medieval traditions, contributing to the continuity of the spirit of the place as a result of the historical itinerary of crafts in urban tradition. Cluj-Napoca is such a city that could develop and support the continuity of its crafts.

4.2. Contributing factors and ways of action in the touristic exploitation of crafts and handicrafts

A SWOT analysis was made from the perspective of continuity, by keeping the authentic spirit of the place in developing and selling handicraft products, with a strong result in the development of handicraft tourism (Table 1). 
Table 1: SWOT analysis of continuity in traditional production, promotion and marketing of handicraft products in Cluj-Napoca

\begin{tabular}{|c|c|}
\hline (S) & We \\
\hline $\begin{array}{l}\text { - the existence of craft associations which provide } \\
\text { information and support in the field; } \\
\text { - the support from the local authorities or support } \\
\text { from the Cluj-Napoca City Council to organise fairs } \\
\text { that promote local tourism and traditional } \\
\text { products; } \\
\text { - the historical tradition of handicrafts in Cluj- } \\
\text { Napoca, forming a reliable basis in the tourism } \\
\text { thereof; } \\
\text { - the existence of an online platform (developed by } \\
\text { Transylvanian Craftsmen Guild Association) and a } \\
\text { Craftsmen Catalogue where craftsmen can promote } \\
\text { for free their work, the existence of the Crafts World } \\
\text { Day, etc.; } \\
\text { - the online marketing platforms on handicraft } \\
\text { products; } \\
\text { - the existence of initiatives to projects, like "The } \\
\text { Fascination of the Craft" - Motivational Project, } \\
\text { made as documentaries to promote the traditional } \\
\text { craft and the forgotten and priceless Romanian } \\
\text { values. }\end{array}$ & $\begin{array}{l}\text { - the lack of legislative regulations in the field; } \\
\text { - the lack of a permanent retail places of crafts; } \\
\text { - the poor promotion of crafts, as well as of the } \\
\text { related events; } \\
\text { - the presence of kitsch products; } \\
\text { - the lack of a common database at the } \\
\text { Romanian national level, so as to allow easy } \\
\text { comparison of the situation in the city with the } \\
\text { rest of the crafts in the country; } \\
\text { - the lack of shared national attestation of } \\
\text { craftsmen; } \\
\text { - the existence of events (fairs, festivals) only } \\
\text { during certain periods (usually for celebrations), } \\
\text { so craftsmen cannot exhibit their products to } \\
\text { trade, only in certain key moments; } \\
\text { - the lack of permanent workshops where guests } \\
\text { can learn about the crafts practiced in the city; } \\
\text { - the lack of tourism products, including crafts as } \\
\text { part of the agreement. }\end{array}$ \\
\hline C & \\
\hline $\begin{array}{l}\text { - accessing European funds to support crafts such as } \\
\text { the National Programme for Supporting Trades and } \\
\text { Crafts; } \\
\text { - including local crafts in the tourist circuit; } \\
\text { - creating a national system of certification of } \\
\text { craftsmen; } \\
\text { - increasing interest in the craft, by producing } \\
\text { modern objects through applying traditional work } \\
\text { methods; } \\
\text { - developing the online marketing of products; } \\
\text { - arrangement and inclusion of workshops and the } \\
\text { tourist circuits; } \\
\text { - increasing the quality of promotional events and } \\
\text { marketing handicraft traders, by not accepting } \\
\text { "artisanal products" made industrial; } \\
\text { - the recent increase of the importance of } \\
\text { handmade as a producing act in the civilized world. }\end{array}$ & $\begin{array}{l}\text { - the increase of the kitsch products at the } \\
\text { organised fairs, which sometimes are more } \\
\text { numerous, outrunning domestic and original } \\
\text { products; } \\
\text { - the downfall of crafts because of the excessive } \\
\text { use of automated mechanisms, modern } \\
\text { technology, industrial processes and, hence, the } \\
\text { loss of interest for handmade products on a } \\
\text { large scale; } \\
\text { - the removal of traditions, knowledge loss and } \\
\text { disappearance of true craftsmen's and artisans' } \\
\text { characteristic techniques, and the present } \\
\text { small number of craftsmen and their aging; } \\
\text { - the focus on the commercial side of crafts. }\end{array}$ \\
\hline
\end{tabular}


Following the SWOT analysis, action in several directions are noted as possibile to promote a genuine development, as well as the cotinuity of Cluj-Napoca traditional production, promotion and marketing of handicraft products:

- accessing EU funds for construction or improvement of permanent handicraft workshops exploited for tourism, so as to avoid losing interest in crafts and the focus on the commercial aspect; instead, the focus will be not only on the final product, but on the learning experience, too;

- creating tourism products, which include crafts, into local and regional tourist circuits;

- establishing of permanent premises for the sale of handicraft products so that the craftsmen could exhibit not only at certain times (fairs, festivals), but throughout the year;

- a more close to traditon selection of the participants during fairs and other events, by improving the quality of promotional events and marketing of handicraft products;

- using the extant online platforms for the promotion of handicrafts and their inclusion in the local tourist circuit.

\section{CONCLUSIONS}

Organising fairs and events, occasioned especially by the celebration of religious holidays, makes possible the craftsmen's marketing of their products, giving them the possibility to generate income from a traditional practice. For the public, it is an easy and feastful way to access traditional products, which, according to the tradition, is synonymous with the main holidays of the year. But most importantly, the fairs generate interaction between the producer and his/her audience through the achieved product, thereby perpetuating the tradition of craftsmanship in the "spirit of place", and shaping the trends in the continuity of the crafts.

As a result of the low income generated by the lack of a permanent disposal of such products, there is, in the craft production, a current tendency to adapt to the request, therefore to the selling aspects, impoverishing the final product, the creation act, and the craftsman who makes it. Public interaction with the craft art and with the creative activity, is reduced, thus, substantially. Therefore, the continuity and the vitality of the old traditions are truncated and they occur only sporadically, boosting the number of objects with non-authentic character, devoid of originality, whose main role is marketing both the producer and the public. It should be noted in this context the lower price of most products. Thus, it appears the danger of losing the essential role of traditional art, producing goods with different uses or decorations that perpetuate the tradition, the authenticity, the uniqueness, generating interaction and sharing craftsman's experience and talent through the creative act. It just defines the craftsman's activity. And the risk is losing the main goal of this activity.

We underline the focus on handicraft and the increased level of craftsmen's training, usually with higher education, same as the increased number of young people, who are, in fact, very receptive to new trends in the handicraft and adapting them, in most cases, happily, to the local spirit.

The framework for the continuity of authentic crafts in Cluj-Napoca is, however, extremely coherent (from the urban tradition of Cluj-Napoca and up to the present development, also the one relating with the city tourism), but because of superficiality in acquiring skills and 
qualification of craftsmen, only the individual conscience and the cultural and the artistic background are making the difference between authentic and non-authentic, maintaining a fragile boundary between the two.

\section{REFERENCES}

ASOCIAȚIA PRODUS DE CLUJ [The Association Made in Cluj], Retrieved September 8 2016, from http://www.produsdecluj.ro/, Retrieved April 32016.

BOLOG, C. (2016). Cluj-Napoca, poartă și inimă a Transilvaniei [Cluj-Napoca, Gate and Heart of Transylvania]. In: IRIMUŞ, I.A., ILOVAN, O.-R., \& BOTAN, C.N. (eds.), Geografia în contextul dezvoltării contemporane (pp. 63-67). Cluj-Napoca: Presa Universitară Clujeană.

BREASLA MEȘTEȘUGARILOR DIN TRANSILVANIA [The Craftsmen's Guild from Transylvania], Retrieved September 8 2016, from http://craftsmen.ro/index.php/ro/

CALDO, C. (1996). Geografia Umana [Human Geography]. Firenze: Palumbo.

CĂLINESCU, M. (2005). Cinci fețe ale modernității. Modernism, avangardă, decadență, kitsch, postmodernism. [Five Faces of the Modernity: Modernism, Avant-garde, Decadence, Kitsch, Postmodernism], $2^{\text {nd }}$ edition. Bucharest: Polirom.

CLUJ-NAPOCA CITY HALL, Retrieved September 8 2016, from www.primariaclujnapoca.ro

COCEAN, P., \& DEZSI, Ș. (2009). Geografia Turismului [The Geography of Tourism]. Cluj-Napoca: Presa Universitară Clujeană.

COHEN, E. (1988). Authenticity and Commoditization in Tourism. Annals of Tourism Research, 15(3), 371386.

DAJ, I., \& STAREȚU, I. (2009). Design de produs şi semiologie Sinteză IV - Procesul de design şi fenomenul kitsch [Product Design and Semiology. Synthesis IV - The Design Process and the Kitsch Phenomenon], Buletinul AGIR nr. 1/2009, Bucharest: Editura AGIR, Retrieved April 3 2016, from http://www.agir.ro/buletine/441.pdf

GOLDENBerG, S. (1958). Clujul în Sec. XVI. Producția și schimbul de mărfuri [Cluj in the $16^{\text {th }}$ Century. Production and Exchange of Goods]. Bucharest: Editura Academiei Republicii Populare Române.

http://atelieruldemestesuguri.worldvision.ro/nv/despre-proiect, Retrieved September 32016.

http://www.iartterritories.com/ro/companii/romania/asociaia-meterilor-populari-clujeni/id/36, Retrieved September 32016.

http://www.iiste.org/Journals/index.php/JEDS/article/viewFile/13216/13331, Retrieved September 8 2016.

https://dexonline.ro/definitie/artizanat, Retrieved February 52016.

https://dexonline.ro/definitie/me\%C8\%99te\%c8\%99ug, Retrieved February 52016.

ICOMOS (2008). Québec Declaration on the Preservation of the Spirit of Place, Retrieved September 9 2016, from http://whc.unesco.org/uploads/activities/documents/activity-646-2.pdf

International. Symposium on "Crafts and the International Market: Trade and Customs Codification", Manila, Philippines (1997). Retrieved April 3 2016, from http://unesdoc.unesco.org/images/0011/001114/111488eo.pdf.

Legea meșteșugurilor - proiect de lege [The Law on Crafts - Law Project], Retrieved February 5 2016, from http://www.senat.ro/legis/PDF\%5C2006\%5C06L904FS.pdf 
Legea $n r .279$ din 5 octombrie 2005 privind ucenicia la locul de muncă [Law no. 279 of the $5^{\text {th }}$ of October 2005 on Apprenticeship at the Workplace] Retrieved September 8 2016, from http://www.mmuncii.ro/pub/imagemanager/images/file/Legislatie/LEGI/L279\%20R-2005.pdf

LITTRELL, M.A., \& DICKSON, M.A. (1999). Social Responsibility in the Global Market. Fair Trade of Cultural Products. California: Sage.

LITTRELL, M.A., ANDERSON, L.F., \& BROWN, P.J. (1993). What Makes a Craft Souvenir Authentic? Annals of Tourism Research, 20(1), 197-215.

LUKACS, J. (2005). Povestea „oraşului-comoară" [The Story of the "Treasure City”]. Cluj-Napoca: Biblioteca Apostrof.

MOLES, A. (1980). Psihologia Kitsch-ului - Arta Fericirii [The Psychology of Kitsch - The Art of Happiness]. Bucharest: Editura Meridiane.

PASCU, Ș. (1954). Meșteșugurile din Transilvania până în secolul al XVI-lea [The Crafts in Transylvania until the $16^{\text {th }}$ Century]. Bucharest: Editura Academiei Republicii Populare Române.

PASCU, Ș. (1974). Istoria Clujului [The History of Cluj]. Cluj-Napoca: Editura Consiliul Popular al Municipiului Cluj.

PASCU, Ș., \& MARICA, V. (1969). Clujul Medieval [Cluj in the Middle Ages]. Bucharest: Editura Meridiane.

RAȚĂ, G., PETROMAN, I., \& PETROMAN, C. (eds.) (2012). The English of Tourism. Cambridge Scholars Publishing.

TOWSEEF, M., LATEEF, A.M., \& SANGRAM, B. (2014). An Analysis of Current Scenario and Contribution of Handicrafts in Indian Economy. Journal of Economics and Sustainable Development, 5(9), 75-78.

(2006). Le Petit Larousse [The Small Larousse]. Paris: Larousse.

(2012). Meșteri și meșteșuguri clujene azi [Crafts and Craftsmen from Nowadays Cluj]. Cluj-Napoca: Tradiții Clujene.

(2015). Cluj-Napoca: Planificarea strategică [Cluj-Napoca: Strategic Planning]. 2014-2020, Retrieved September 8 2016, from http://cmpg.ro/wp-content/uploads/2015/05/strategie-cluj-napoca2014-2020.pdf 